\title{
Chapter 2 \\ Composting as a Municipal Solid Waste Management Strategy: Lessons Learned from Cajicá, Colombia
}

\author{
Cristian Rivera Machado and Hiroshan Hettiarachchi
}

\begin{abstract}
Municipal solid waste (MSW) generated in developing countries usually contains a high percentage of organic material. When not properly managed, organic waste is known for creating many environmental issues. Greenhouse gas (GHG) emissions, soil and water contamination, and air pollution are a few examples. On the other hand, proper and sustainable management of organic waste can not only bring economic gains but also reduce the waste volume that is sent for final disposal. Composting is one such recovery method, in which the end product - compost eventually helps the agricultural industry, and other sectors, making the process an excellent example of nexus thinking in integrated management of environmental resources. The aim of this chapter is to discuss how Cajicá, a small city in Colombia, approached this issue in a methodical way to eventually became one of the leading organic waste composting examples in the whole world, as recognised by the United Nations Environment Programme in 2017. Cajicá launched a source separation and composting initiative called Green Containers Program (GCP) in 2008, based on a successful pilot project conducted in 2005. The organic waste separated at source collected from households, commercial entities, schools, and universities are brought to a privately operated composting plant chosen by the city to produce compost. The compost plant sells compost to the agricultural sector. The participants in the GCP could also receive a bag of compost every 2 months as a token of appreciation. The Cajicá case presents us with many lessons of good practice, not only in the sustainable management of waste but also in stakeholder engagement. It specifically shows how stakeholders should be brought together for long-lasting collaboration and the benefits to society. Finding the correct business model for the project, efforts made in educating the future generation, and technology adaptation to local conditions are also seen as positive experiences that others can learn from in the case of Cajicá's GCP. Some of the concerns and potential threats observed include the high dependency GCP has on two institutions: the programme financially depends completely on the municipality, and the composting operation
\end{abstract}

C. R. Machado $\cdot$ H. Hettiarachchi $(\square)$

United Nations University (UNU-FLORES), Dresden, Sachsen, Germany

e-mail: hiroshanh@gmail.com 
depends completely on one private facility. GCP will benefit from having contingency plans to reduce the risk of having these high dependencies.

Keywords Cajicá Municipality $\cdot$ Colombia $\cdot$ Compost $\cdot$ Municipal solid waste $(\mathrm{MSW}) \cdot$ Nexus thinking $\cdot$ Organic waste $\cdot$ Waste management

\section{Introduction}

Organic waste is known for posing a wide range of environmental challenges such as leachate production, greenhouse gas (GHG) emissions, offensive odours, and soil/water contamination, when they are disposed in landfills or especially uncontrolled dump sites (Hettiarachchi et al. 2018a). On the other hand, the same can be put to good use by society, if managed properly using sustainable recovery alternatives such as composting, anaerobic digestion, and thermal treatment. Such techniques can help us significantly reduce the organic waste that goes for final disposal in landfills and dump sites (Pace et al. 2018). These alternatives also offer other environmental benefits such as reduction of GHG emissions and leachate production in landfills (USEPA 2016; Adhikari et al. 2009). When used as soil amendments, the composting option also provides nutrient recycling, increased water retention capacity, and improved soil structure (Wei et al. 2017).

Municipal solid waste (MSW) produced in low- and middle-income countries usually has a much higher organic fraction compared to the same volume in highincome countries (Kaza et al. 2018). This is also true for the Latin American and Caribbean (LAC) region where 52\% of the MSW produced is organic. High organic content means that there is room for recovery such as making compost or biogas production (Hettiarachchi et al. 2018a, b). Since waste separation is not a common practice in the region, they miss an opportunity for resource recovery as well as generation of some cash from such recovery activities. However, there is one community in LAC that went against all odds to make composting as a part of their municipality's MSW management strategy and finally became a world-class example in 10 years. This community is in Cajicá, Colombia.

Cajicá Municipality started organic waste composting as a pilot project in 2005. Since the success depends heavily on source separation, they put a lot of efforts in awareness-raising campaigns. With positive results from the pilot, finally they launched the full programme in 2008 which was eventually called the Green Containers Program (GCP). Now, after 10 years, they have accomplished much success. In 2017, UN Environment selected five cities from around the world to highlight new experiences with a strong approach to waste management (UN Environment 2017). Cajicá (Colombia) was among these five cities together with Osaka (Japan), Alappuzha (India), Ljubljana (Slovenia), and Penang (Malaysia). In the case of 
Cajicá, it was selected mainly because of the Green Containers Program launched by the Cajicá Municipality about a decade ago.

This manuscript presents the case of Cajicá starting from 2005 to the present situation. In addition, a review of MSW and MSW management in Colombia is also presented prior to that from the material as well as policy perspectives. The Cajicá example is then presented considering the institutional, educational, social, technological, environmental, and financial aspects of the scheme. Such information may be particularly useful for other municipalities, especially in developing countries, to improve their performance in waste management.

\section{Waste Management in Colombian Municipalities}

Colombia generates about 32,000 tons of MSW daily, out of which $85 \%$ is disposed or treated, while the rest goes into recycling (DNP 2016). Landfilling is now the most widely used technique for final disposal throughout the country, and in 2016, almost 11 million tons of MSW was disposed in Colombian landfills. The MSW collected by Colombian municipalities usually presents a consistently high percentage of organic waste. For instance, Bogotá generated 57\% organic waste, $13.25 \%$ plastic, $8.92 \%$ paper and paperboard, $1.91 \%$ textiles, $1.30 \%$ wood, $1.12 \%$ metals, $2.76 \%$ glass, and $1.99 \%$ other wastes (Alcaldía de Bogotá 2015). The MSW composition in Colombian municipalities is somewhat homogeneous as evident in Fig. 2.1. With this high organic content in MSW, much of it can be valorised through composting or biogas production.

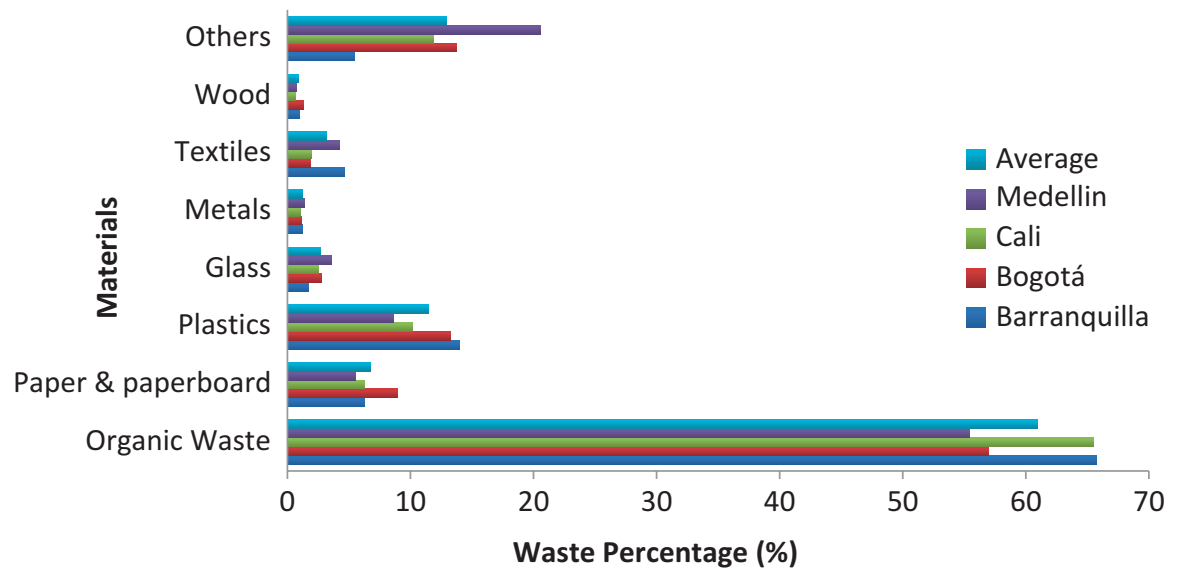

Fig. 2.1 Waste characterisation and comparison in the principal cities of Colombia. (Source: Alcaldía de Barranquilla 2015; Alcaldía de Bogotá 2015; Alcaldía de Medellín 2015; Alcaldía de Santiago de Cali 2015) 
Between 2005 and 2014, the national collection rate increased from $75.8 \%$ to $80 \%$, and urban collection rate increased from $94.6 \%$ to $97.8 \%$. At the national level, about $73 \%$ is served by private vendors that have financial capacity to provide a reasonable sanitary service (Banco Mundial 2015). However, there are still deficiencies in infrastructure and institutional capacities to serve rural areas. Waste collection coverage in rural Colombia is at about 24\% (DANE 2013).

Until the 1980s and 1990s, open dumps were the predominant waste disposal facilities in Colombia. However, with a mixture of regulations, sanctions, and financial instruments introduced in the recent past, disposal in the open dumps is finally coming to an end, though gradually (DNP 2016). In addition, Colombia has also made progress with the application of better business models in the sanitary services sector, which has also resulted in increased waste collection rates in the urban areas and better quality in the final disposal methods and facilities (DNP 2016).

Landfilling is the final disposal method recommended in the national regulation, and currently 891 municipalities use landfills. Another 110 municipalities continue to practise open dumping, burying, burning, and disposing in waterbodies (Superintendence of Public Services 2017). The inadequate environmental performance of some of the landfills is also a major concern. In 2011, at least $30 \%$ of all the landfills in the country did not comply with environmental standards and regulation (OECD/UN ECLAC 2014).

Waste recovery in Colombia is mainly limited to the recycling of paper, cardboard, plastics, and metals. Other sustainable recovery methods pertaining to organic waste such as nutrient recovery through composting or energy recovery through biogas production have not become well recognised yet. Recycling is conducted by a workforce engaged in collection: 13,984 organised waste pickers and another 12,000 in the informal sector. In Bogotá alone, around 14,000 waste pickers depend on formal and informal recycling as their livelihood. Approximately $55 \%$ of the municipal-level recycling is the result of the informal sector (OECD/UN ECLAC 2014) although scavenging on landfills/dump sites was prohibited through the National Decree 1713 of 2002.

\subsection{Policy Support Received by Municipalities}

The institutional framework for MSW management in Colombia is characterised by multiple actors that can be clustered into three tiers. At the national level, three ministries and a national authority are involved - Health, Environment, and Housing - as well as the Superintendence of Household Public Services. At the regional level, the environmental authorities are in charge of regulation enforcement and monitoring. At the local level, the municipalities are in charge of the implementation of the MSW management policies.

The policy framework of MSW management in Colombia has evolved much during the past two decades. The basic structure was established in 1994 through Law 142 on Household Public Services. In 1998, the National Policy of Integrated 
Waste Management emphasised on the objectives to minimise the generation of waste, increase recovery, and use landfills for final disposal. In 2002, Decree 1713 defined the concepts related to waste management and the requirements for the management of MSW, regarding the collection, recycling, and disposal (OECD/UN ECLAC 2014).

Based on the Regulation 1045 of 2003, every municipality is required to develop an Integrated Solid Waste Management Plan or more popularly known by its Spanish acronym PGIRS. This plan (PGIRS) defines the mechanisms, responsibilities, and methodologies for the municipalities to become guarantors of MSW management in their jurisdictions. PGIRS developed based on Regulation 1045 of 2003 was later found to be rather weak for practical formulation and implementation (Ministry of Housing, Cities and Territories 2014). As a result, the Ministry of Environment, together with the Ministry of Housing, issued a reformulated methodology - Regulation 754 of 2014. It consisted a new approach and contained features that could promote better ways to design and implement PGIRS in the entire country. PGIRS is perhaps the most important municipal waste management regulation introduced thus far in Colombia.

The National Decree 1077 of 2015 (before Decree 2981 of 2013) describes the municipal-level sanitary services for the entire country. These activities are (1) collection, (2) transport, (3) sweeping and cleaning of roads and public areas, (4) washing of public areas, (5) lawn mowing and tree pruning in public areas, (6) transfer, (7) treatment, (8) recovery and valorisation (without energy recovery), and (9) final disposal (Ministry of Housing, Cities and Territory 2015). The tariff framework included in Regulation 720 of 2015 (issued by the Regulatory Commission for Drinking Water and Basic Sanitation (CRA)) has fixed ceiling prices defined for waste management and sanitary services.

Waste recovery is yet to receive the attention of the policy sector. As mentioned, recycling has been carried out significantly by waste pickers. Thanks to some progressive steps made in the 1990s such as the creation of the Ministry of Environment, several regulations were introduced later recognising the role of waste pickers and identifying them as a vulnerable community (Red de ciudades cómo vamos 2014). However, only until the introduction of a new policy on waste management, CONPES 3874 in 2016, which enabled some nutrient recovery activities such as composting to foster.

\subsection{Cajicá Municipality, Colombia}

Cajicá is a municipality located in the Bogotá metropolitan area. It is positioned in the north of the Capital District, $39 \mathrm{~km}$ from Bogotá, at an altitude of $2598 \mathrm{~m}$ above sea level. It is surrounded by the municipalities of Zipaquirá to the north, Chia to the south, Tabio to the west, and Sopó to the east (Alcaldía Municipal de Cajicá 2018). As per the Colombian National Census conducted, Cajicá's population in year 2005 was 44,721 . The projections made based on the last survey estimates the population 
for 2019 to be 61,549 with a distribution of $63 \%$ in urban settings and the rest in the rural areas (DANE 2005). The Sanitary Collection Enterprise (EPC) (Spanish acronym) is the entity in charge of Cajicá's sanitary services, under the authority of the municipality, and mainly owned by the municipality. Their service covers different categories of customers such as households, industries, and commercial entities. In the case of households, they are further classified into six categories called Socioeconomic Classes (SECs) based on income (the lowest-income households in SEC 1 and the highest in SEC 6). SEC statistics for the period 2010-2014 are presented in Fig. 2.2. In 2014, the coverage of sanitary collection service for the Cajicá urban areas reached almost 100\% (DANE 2014).

MSW Generation and Composition in Cajicá The waste generation rate in Cajicá has been continuously increasing during the past decade. Increase in population, growth of the middle class, changes in consumption habits, and urban expansion are among the main reasons. Table 2.1 presents the daily average MSW generation data per capita for Cajicá from 2009 to 2014 (Alcaldía Municipal de Cajicá 2015).

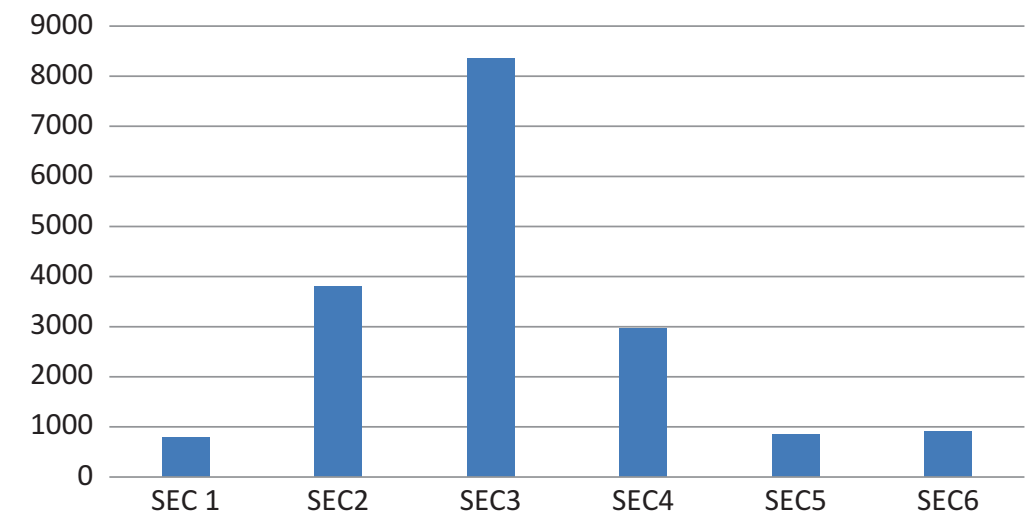

Fig. 2.2 Customers of sanitary service in 2015 per SEC criteria. (Source: Alcaldía Municipal de Cajicá 2015)

Table 2.1 Per capita MSW generation in Cajicá from 2009 to 2014

\begin{tabular}{l|l}
\hline Year & $\begin{array}{l}\text { MSW generation per capita }(\mathrm{kg} / \\
\text { capita/day) }\end{array}$ \\
\hline 2009 & 0.58 \\
\hline 2010 & 0.62 \\
\hline 2011 & 0.66 \\
\hline 2012 & 0.72 \\
\hline 2013 & 0.78 \\
\hline 2014 & 0.84
\end{tabular}

Source: Alcaldía Municipal de Cajicá (2015) 
Figure 2.3 presents the composition of MSW that reached the final disposal from Cajicá. The low fraction of organic waste in it is clearly visible. This is due to the organic waste composting programme currently run by the municipality of Cajicá, which is the focus of this manuscript.

Final Disposal of MSW in Cajicá "Nuevo Mondoñedo" landfill is the facility used for final disposal of MSW collected in Cajicá. It is a landfill that serves 80 municipalities in the region, located in Bojacá which is about $50 \mathrm{~km}$ from Cajicá. The amount of MSW disposed has been increasing in the recent years according to data presented in Fig. 2.4. The sudden drop in waste disposal between 2008 and 2009 is believed to be due to the diversion of organic fraction from landfill to sustain

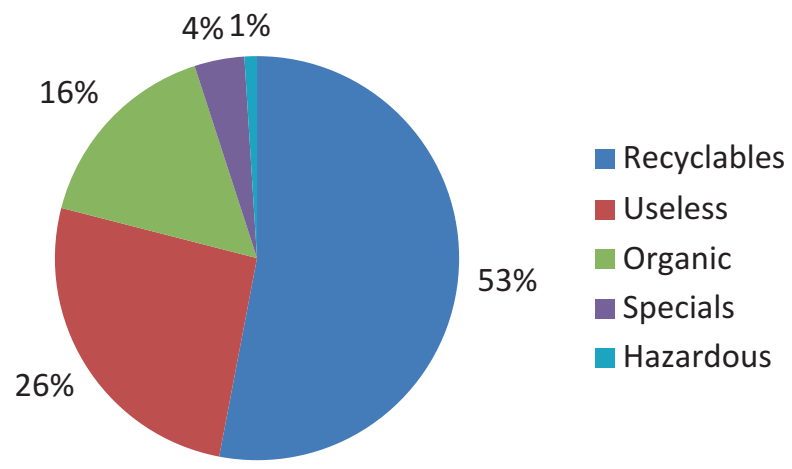

Fig. 2.3 Cajicá's waste characterisation in the landfill in 2014. (Data: Alcaldía Municipal de Cajicá 2015)

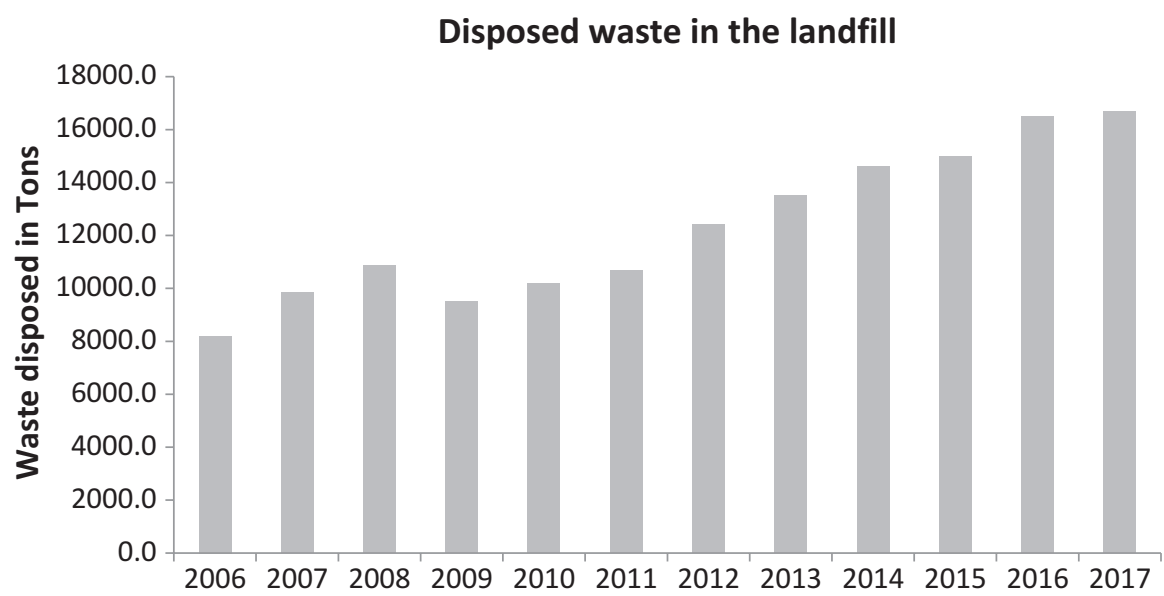

Fig. 2.4 Cajicá's disposed waste between 2006 and 2014. (Data: Alcaldía Municipal de Cajicá 2015, and information given personally in Cajicá by EPC in November 2018) 
the composting programme, as the timing coincides with the start of the Green Containers Program (Alcaldía Municipal de Cajicá 2015).

\section{Green Containers Program: The Composting Initiative Launched by the Cajicá Municipality}

The organic waste recovery efforts in Cajicá began in 2005 as a small composting pilot project conducted by the municipality. Cajicá Municipality, EPC (which was introduced earlier), and some motivated residents initiated a small organic waste source separation campaign to feed the composting pilot project. They collected 2 tons of organic waste through composting and vermiculture and converted compost during the pilot, which was distributed among the participating families (Ospina 2009). The pilot was a significant experience that allowed the Cajicá Municipality to gather convincing data, experience, and arguments to scale up the project to reach its status today.

Based on the above experience, Cajicá Municipality officially launched a source separation and citizen awareness programme mainly focusing on organic waste management through the Decree 061 of 2005 . The programme aimed to increase the awareness of citizens in source separation for composting and recycling and instil good practices of sustainable waste management (Alcaldía Municipal de Cajicá 2015). The programme was planned and developed between 2006 and 2008 with the involvement of the following stakeholders from the region: Cajicá Municipality, the public, EPC, waste facility managers, government environmental authority, and industries. Then, at the end of 2008, the source separation programme called Green Containers Program (GCP, hereafter) was born, initially focusing only on some selected neighbourhoods.

Cajicá's Municipality began to distribute green plastic containers (as the name of the programme suggests) among the participants of the programme. They were distributed for free to the SEC groups 1-4, and they were sold to the SEC groups 5 and 6 and other customers. Within the next few years, the programme was expanded to cover more neighbourhoods. Between 2008 and 2014, the number of green containers distributed was 14,408: except for about 1000 replacement containers, all others were for new participants (Alcaldía Municipal de Cajicá 2015). GCP participation is not only from the households: there are other institutional participants such as industries, commercial entities, educational institutions, and government institutions (Alcaldía Municipal de Cajicá 2015). Depending on the need of the customers and the expected volume, GCP offers three container sizes: 10, 20, and 30 litres in volume. The containers incorporate a false bottom in order to collect leachates.

The frequency of the organic waste collection in Cajicá is once per week. As such, the GCP participants must mix the organic waste with a substance called bokashi - a mixture of effective microorganisms (EM) and wheat bran. When mixed with organic waste, bokashi prevents offensive odours inside the house and also 
catalyses the composting process (Alcaldía Municipal de Cajicá 2015). Cajicá's GCP delivers a $1.5 \mathrm{~kg}$ pack of bokashi to all its participants around every 2 months for free.

Cajicá Municipality was successful in letting the financial investment made towards the GCP grow continuously over time, which led to the improvement in services and the organic waste collection coverage in both urban and rural areas. The specific budget for the GCP for the period of 2016-2019 is around USD 364,000 per year (based on the average exchange rate for 2015, USD $1=$ COP 2743). The budget is mainly distributed among the following activities (personal communication with Javier Rodríguez, Head of Waste Management of Cajicá's Sanitary Collection Enterprise, May 2018):

- Raw materials and workspace for bokashi manufacturing

- Cost of green containers

- Awareness-raising campaigns and programme advertising

- Trainers for awareness campaigns and capacity building (as of now GCP has 18 full-time trainers)

\subsection{Organic Waste Source Separation: Awareness Raising}

The success of an organic waste composting programme depends on the quality of the material received. Many waste composting programmes have failed in the past due to quality issues (Hettiarachchi et al. 2018a). One unique aspect of Cajicá's composting programme is the commitment the municipality has made to raise the awareness in organic waste source separation among all stakeholders from all sectors including households, commerce, industry, official institutions, schools, and universities. This public commitment started during the composting pilot mentioned above and has evolved in different ways over the years.

Cajicá's educational programme is now equipped with various tools and methods such as games, hands-on activities, brochures, videos, and workshops, which are useful to send an effective message about source separation of organic waste. Figure 2.5 presents one such educational poster distributed among residents to increase awareness about source separation. The poster describes in seven steps the correct procedure to handle the green containers: (1) use the false bottom container; (2) spread a spoonful of bokashi at the bottom of the container; (3) throw the separated waste on the bokashi; (4) spread a spoonful of bokashi every night; (5) compress the waste in order to release any air; (6) seal the container tightly; and (7) drain the liquids twice a week and deposit them in the siphon or use it as fertiliser for your plants after diluting with water.

Bokashi distribution mentioned above is conducted as a door-to-door service carried out by trained personnel. The GCP uses this as an in-person training opportunity to answer any question participants may have on the process. In addition, GCP has also conducted several training workshops to raise awareness across 


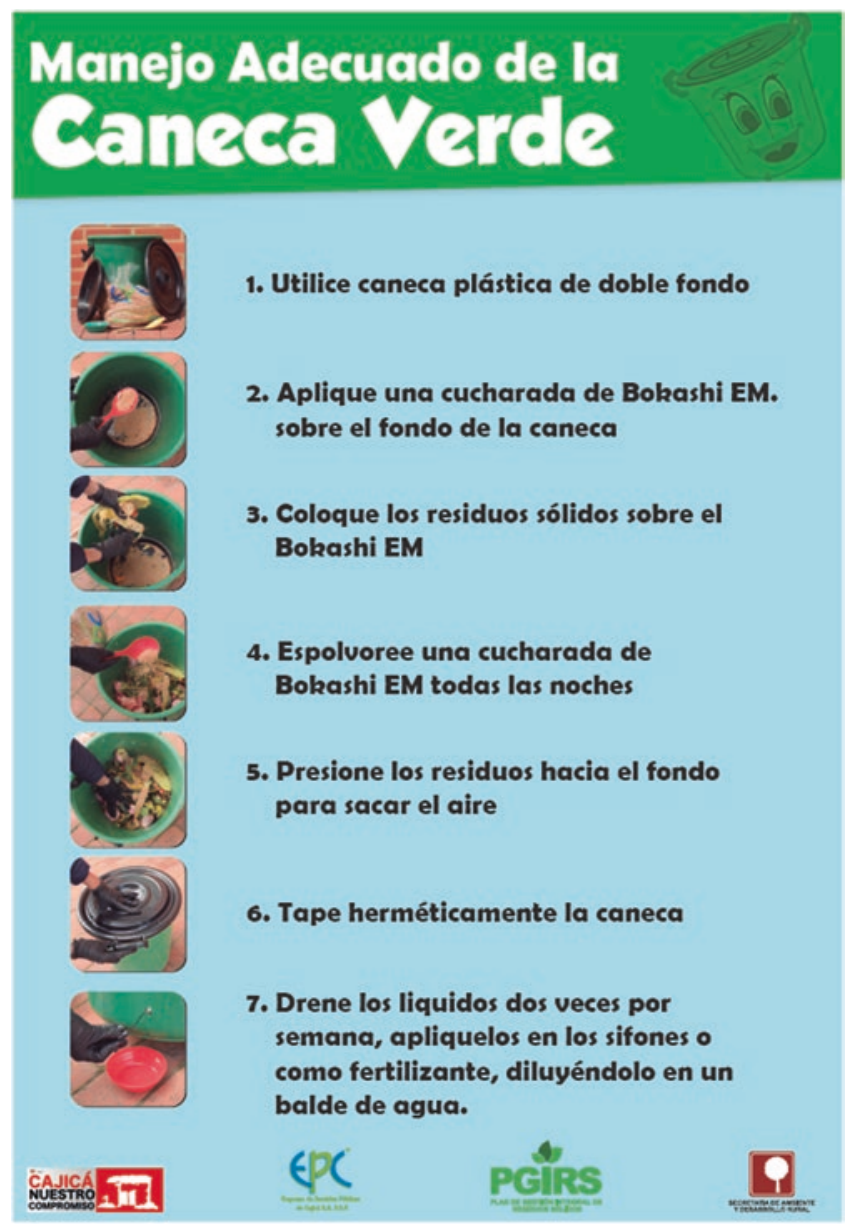

Fig. 2.5 Educational brochure about source separation, Green Containers Program, and EM's good practices. (Poster courtesy: Cajicá Municipality)

various segments of society. A summary of the workshops conducted in 2017 is presented in Table 2.2. The care and attention they have put towards the next-generation participants is very much visible in the numbers associated with schools and kindergartens.

\subsection{Composting Process and Quality Control}

According to Cajicá's Integrated Solid Waste Management Plan (Cajicá PGIRS, hereafter), in 2015, EPC managed to increase the coverage of collection of organic waste to $95 \%$ in the urban area, although the coverage in the rural areas was still low 
Table 2.2 Participant breakdown for the awarenessraising workshops conducted in 2017

\begin{tabular}{|c|c|}
\hline Customer type & $\begin{array}{l}\text { Number of } \\
\text { trained people }\end{array}$ \\
\hline Residential buildings & 791 \\
\hline Single-family households & 1715 \\
\hline Commerce & 310 \\
\hline Industries & 383 \\
\hline Government institutions & 112 \\
\hline Schools & 4026 \\
\hline Kindergartens & 1120 \\
\hline Total & 7177 \\
\hline
\end{tabular}

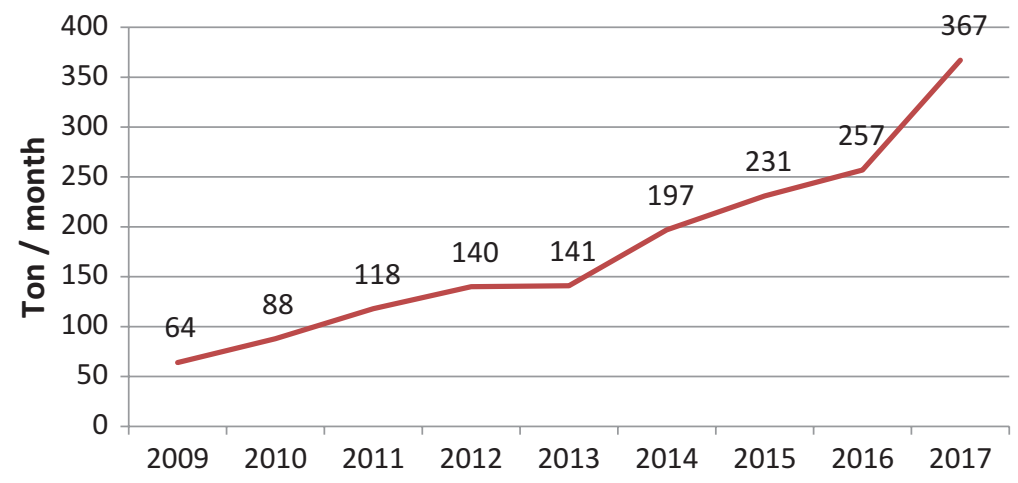

Fig. 2.6 Organic waste recovery from 2009 to 2014. (Data: Sanitary Collection Enterprise of Cajicá 2017, and personal communication with EPC in Cajicá November 2018)

(Alcaldía Municipal de Cajicá 2015). The total amount of organic waste recovered is also increasing steadily as evident in Fig. 2.6. In addition to the expansion of the collection routes, there are also other reasons behind this success, such as the increased public acceptance of the programme and the awareness-raising activities (Alcaldía Municipal de Cajicá 2015).

The organic waste collected by EPC is then shipped to a facility operated by IBICOL SAS - a private vendor located in Tocancipá for composting and marketing the compost (see Fig. 2.7). The substrate consists mainly of separated organic waste from the Cajicá Municipality, agricultural waste from flower and tomato plantations, and some industrial organic waste in the form of milky sludge.

IBICOL SAS is a Colombian company in operation since 2007 and offers sustainable alternatives that support agricultural and livestock management and has a partnership with the Midwest Bio-Systems in the United States (IBICOL SAS 2018). The workflow between the Cajicá Municipality and IBICOL SAS has been established through a contractual agreement made between EPC and IBICOL 


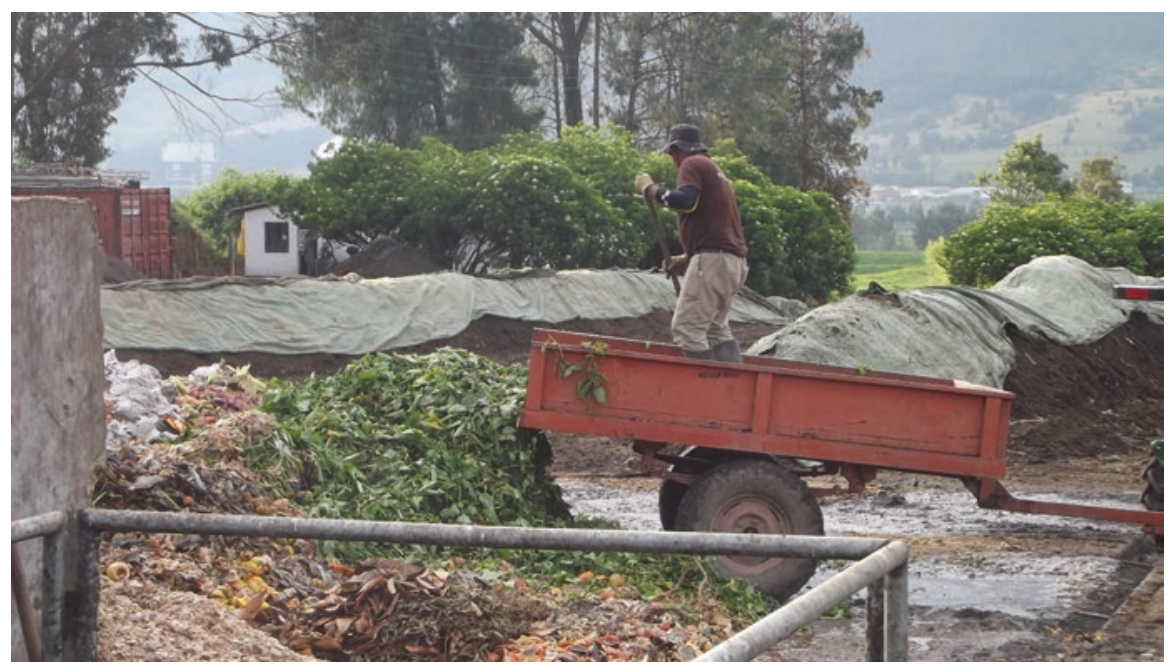

Fig. 2.7 Composting in operation at the IBICOL SAS facility as organic waste received is being unloaded. After $24 \mathrm{~h}$, this waste is transferred to the piles seen in the background for the next stage of processing (Photo taken by the authors in November 2018 with courtesy of the General Manager of the Facility, Mr. Francisco Pradilla)

SAS. Both parties work together to define the cost of the recovery process to be paid by EPC (Alcaldía Municipal de Cajicá 2015).

The composting workflow at the facility is divided into three parts: (1) reception zone (solid and liquid waste), (2) composting zone, and (3) compost storage zone. IBICOL SAS follows a specific set of standards and control procedures to maintain the quality of the product. They constantly measure and control temperature, humidity, aeration, and evolving $\mathrm{CO}_{2}$. Samples from the final product are routinely subjected to laboratory testing such as elemental, proximate, and carbon-nitrogen ratio analysis for quality control purposes. The composting facility has the capacity to treat 1000 tons of organic waste each month. The current technology uses the Aeromaster PT-120 (pull-type) compost windrow turner, which works on three aspects concurrently: windrow turning and watering, addition of inoculants, and reshaping of the windrow. The average process time is around 10 weeks for the mesophyll and thermophile phases.

IBICOL SAS sells compost to the agricultural sector (mainly flower and vegetable growers in Cundinamarca); the municipalities to use in parks, green areas, and public gardens; and other sectors such as mining and landfilling. To achieve sales targets and maintain their customer base in the region, it is important that they maintain the quality of their products. IBICOL SAS conducts frequent sampling and testing to compare compost quality with the Colombian National Standards (NTC 5167). Table 2.3 presents a comparison between the IBICOL SAS compost characterisation and the Colombian National Standards. It is evident from Table 2.3 that except for one parameter (total oxidisable organic carbon), Cajicá's compost meets the Colombian quality standards reasonably well. 
Table 2.3 Typical compost characterisation and Colombian regulation standards

\begin{tabular}{l|l|l|l}
\hline & Units & $\begin{array}{l}\text { NTC 5167 (Colombian National } \\
\text { Standard) }\end{array}$ & $\begin{array}{l}\text { IBICOL test } \\
\text { results }\end{array}$ \\
\hline Lasses due to volatilisation & $\%$ & & 43.5 \\
\hline Ash & $\%$ & $\leq 60$ & 22.7 \\
\hline Moisture & $\%$ & $\leq 35$ & 33.8 \\
\hline $\begin{array}{l}\text { Total oxidisable organic } \\
\text { carbon }\end{array}$ & $\%$ & $\geq 15$ & 14.5 \\
\hline Total phosphorus (P205) & $\%$ & Declare if greater than 1 & 1.09 \\
\hline Total potassium & $\%$ & Declare if greater than 1 & 1.69 \\
\hline C/N relation & & & 11 \\
\hline Cation exchange capacity & $\mathrm{meq} / 100 \mathrm{~g}$ & $\geq 30$ & 30.6 \\
\hline Moisture retention & $\%$ & 100 & 120 \\
\hline pH & & Between 4 and 9 & 8.25 \\
\hline Density & $\mathrm{g} / \mathrm{cm} 3$ & $\leq 0.6$ & 0.46 \\
\hline Arsenic $(\mathrm{As})$ & $\mathrm{ppm}$ & 41 & $\mathrm{ND}^{\mathrm{a}}$ \\
\hline Cadmium $(\mathrm{Cd})$ & $\mathrm{ppm}$ & 39 & 0.18 \\
\hline Chrome $(\mathrm{Cr})$ & $\mathrm{ppm}$ & 1200 & 7.5 \\
\hline Mercury $(\mathrm{Hg})$ & $\mathrm{ppm}$ & 17 & $\mathrm{ND}^{\mathrm{a}}$ \\
\hline Nickel $(\mathrm{Ni})$ & $\mathrm{ppm}$ & 420 & 6.13 \\
\hline Lead $(\mathrm{Pb})$ & $\mathrm{ppm}$ & 300 & 1.42 \\
\hline
\end{tabular}

Data: Norma Técnica Colombiana (2004), IBICOL SAS (2018)

${ }^{\mathrm{a}} \mathrm{ND}$ no detection

\section{Discussion: Lessons from Cajicá}

With the information presented in the previous sections, it is fair to say that Cajicá is a case study that tells a success story. There are some interesting observations that we consider as the key reasons behind the success the project achieved in 10 years with a continuous growth. Key features are discussed briefly below and might be considered as valuable tips for other municipalities, especially in developing countries that are considering initiating composting or other types of waste recovery projects. At the end of this section, we also briefly discuss some of the potential concerns and threats that we have observed while analysing Cajicá GCP.

\subsection{Proper Planning and Stakeholder Involvement}

Cajicá PGIRS briefly introduced before played a vital role in shaping the waste management activities in Cajicá. The methodology for PGIRS development stresses on the need to consult other existing municipal plans (such as land use plans, basin plans, etc.) during the PGIRS design phase to achieve synergies and avoid inconsistencies (Ministry of Housing, Cities and Territory 2014). Cajicá PGIRS also 
Table 2.4 Organic waste management synergies between Cajicá PGIRS and the MDP from 2008 to 2019

\begin{tabular}{l|l}
\hline $\begin{array}{l}\text { Municipal } \\
\text { Development Plan } \\
\text { (MDP) }\end{array}$ & Relation with Cajicá PGIRS and \\
\cline { 2 - 2 } $\begin{array}{l}\text { 2008-2011 "Cajicá } \\
\text { standing the change } \\
\text { is with all" }\end{array}$ & $\begin{array}{l}\text { The programme called "Expansion of coverage, reposition of networks, } \\
\text { and improvement of quality for the provision of home public services" } \\
\text { aimed to increase the coverage of cleaning services, implement the } \\
\text { PGIRS, and encourage source separation and waste recovery and } \\
\text { recycling }\end{array}$ \\
\hline $\begin{array}{l}\text { 2012-2015 "Progress } \\
\text { with social liability" }\end{array}$ & $\begin{array}{l}\text { The Clean Municipality programme, aimed to increase the coverage of } \\
\text { cleaning services, adjust and implement the PGIRS, increase the } \\
\text { collection of organic waste, and implement a strong educational } \\
\text { campaign for the GCP }\end{array}$ \\
\hline $\begin{array}{l}\text { 2016-2019 "Cajicá, } \\
\text { our commitment" }\end{array}$ & $\begin{array}{l}\text { The programme "Efficient and quality public services for Cajicá" } \\
\text { established the objective to strengthen the GCP, the source separation, } \\
\text { and also the formulation and implementation of a public recovery } \\
\text { organic waste facility }\end{array}$ \\
\hline
\end{tabular}

Source: Concejo Municipal de Cajicá (2007, 2011, 2015)

established this coherence between other existing plans in order to be efficient in public management and achieve a greater impact. Especially in the case of Cajicá, the other plan available is the Municipal Development Plan (MDP) made for every 4 years. Table 2.4 presents a summary of organic waste management synergies we observed between Cajicá PGIRS and their MDP.

Cajicá PGIRS has improved over time. The first version of the plan was announced in 2005, and it was updated in 2010 and then updated again in 2015 due to regulation changes and new guidelines mandated by the Ministry of Housing and the Ministry of Environment. These ministerial guidelines recommend that the PGIRS design must be from an interdisciplinary perspective with participation of different stakeholders from the municipality. That was exactly what Cajicá did: all Cajicá PGIRS versions were designed with the participation of representatives from the municipality, EPC, schools, universities, public institutions, non-governmental organisations (NGOs), waste pickers, and regional environmental authority.

This experience helped Cajicá to build a stronger PGIRS and the basis for smooth implementation. For instance, in 2014 during the Cajicá PGIRS updating process, the municipality signed an agreement with CEMPRE (a Latin American NGO that works in recycling) in order to help them with the social aspects of the recycling scheme and waste picker socio-economic conditions (Alcaldía Municipal de Cajicá 2015). Likewise, some other agreements with the environmental authority (CAR) and IBICOL were developed.

For Cajicá PGIRS implementation and monitoring purposes, a team comprising of EPC and the environmental office of the municipality was established. The team followed a Plan-Do-Check-Act (PDCA) strategy to achieve better results. According to EPC, continuous practice of PDCA has helped to improve the service, reduce environmental impacts, prevent risks, and reduce costs in the processes of source 
separation, collection, and transport of waste (personal communication with Javier Rodríguez, Head of Waste Management of Cajicá's Sanitary Collection Enterprise, May 2018).

\subsection{The Business Model and Governance Aspects}

Finding the correct business model and governance structure was also crucial for the success of the GCP. A composting operation must be carried out with a business perspective and sound administrative/organisational plan. Ekelund and Nyström (2007) pointed out that it is also important to have strong working relationships with external agents who can provide technical, commercial, financial, and research support. It is important to mention that IBICOL SAS facility possesses all of the above to win a local reputation as an outstanding organic waste composting plant. Their strength as a composting facility can be attributed to the following factors: solid business model/strategy; close relationship with the municipality of Cajicá; guaranteed suppliers; high procedural and operational standards; diversification of products and customers; and partnerships with technology suppliers from the United States.

Governance structure decides how political power is exercised to manage economic and social resources for development (World Bank 1994), which is usually categorised into three types based on the type of main actors involved: bureaucratic governance, market governance, and network governance (Thompson et al. 1991). Hettiarachchi et al. (2018b) described how these three types of governance may be involved in waste management activities. In Cajicá, the GCP benefitted from the co-coexistence of mainly two types of governance: bureaucratic and network.

Bureaucratic governance (also known as hierarchy governance) is about following rules, as defined by the hierarchical authorities such as governments (Colebatch and Larmour 1993). Cajicá Municipality has achieved an elevated position within the country based on the positive bureaucratic governance it has exhibited. The Colombian Municipal Performance Measurement (MPM) is a national index that aims to measure and compare the performance of municipalities in the entire country. The index encompasses variables such as administrative efficiency, compliance with the goals of their development plans, provisioning of basic services, budget execution, improvements in the welfare of the population, transparency, and administrative and fiscal management (DNP 2016). The MPM outcome of 2016 positioned Cajicá within the 10 best municipalities out of 217 in the same category (DNP 2016). It is a tremendous achievement and an accolade for the municipality for the steps taken to guarantee improvements in the welfare of the population.

Network governance constitutes a distinct form of coordinating economic activity, which combines markets and hierarchies (Jonas et al. 1997). It is a democratic decision-making process, within the context of sustainable development and publicprivate partnership (PPP) (Hettiarachchi et al. 2018b). This feature was clearly visible throughout the establishment and running of the GCP. In Cajicá, stakeholders 
such as IBICOL SAS and EPC play active and important roles in the GCP. Their collaboration with the municipality to run the GCP has created more than 50 job opportunities for people.

PPP in Cajicá has also found to be effective in relation to the residential apartment buildings. EPC, residents' associations, and some construction companies collaborated to develop a construction guide for residential apartment buildings to ensure enhanced capacities for source separation and waste management. In the guide, the construction companies can find standards for the waste collection room, recommendations for ventilation inside the kitchens, and finally, to foster source separation, a clause that recommends against the installation of garbage chutes.

\subsection{Educating the Next Generation}

Environmental education among the public has played an important role in the process of development and maintenance of GCP. Cajicá has implemented different strategies for environmental and waste management education, especially through programmes launched at schools and universities. The basis of the successful source separation model of organic waste was explained to the public through the Decree 061 in 2005 (called "Citizen culture for the integral management of solid waste and the program of separation at the source") and then further enhanced through the Decree 003 in 2011.

As seen in Table 2.2, the municipality has a strong commitment towards awareness raising among school children. One of the aims of this effort is to enable children to take the "organic waste recovery message" home to educate their families. The GCP approaches students through some composting and farming projects at schools and catches their attention with the learning-by-doing concept. It has provided conclusive evidence that such education programmes can play a key role in developing children's knowledge about sustainable waste management. The project also concludes that if the message delivered in school is taken home, waste management at homes becomes more sustainable. In addition, EPC organises "Eco-Arte" an annual school contest on the topic of waste management through arts in different categories. The idea is to construct artwork with recycled materials during the school year, and then in November, the best school wins a prize. This practice has helped them make source separation more popular and improve environmental awareness.

One of the most innovative aspects of the education programme in Cajicá is the work done by the trainers. There are about 18 trainers who are specialised in addressing different customer groups (residential, commerce, industry, public, etc.). It is important to note that they have appointed such specific trainers for schools and universities, too. There is also one trainer working exclusively on social media and advertising, who is able to catch the attention of the younger generation, especially students. 


\subsection{Technology Adaptation to Local Conditions}

Technology transfer from developed and developing countries does not always go as planned due to the complexity of the technology or the lack of capacity building at the final user. On the other hand, correctly managed technical adaptation can increase the amount of materials recovered, reduce problems in operation and maintenance of equipment and machinery, and positively influence systems sustainability (Oviedo-Ocaña et al. 2016). In this context, adaptation of technology to the local settings was a key part of the success of Cajicá. One might argue that composting is a very well-established process that does not need much adaptation. This is true about the compost making process. However, some fine-tuning is still needed to arrange properly all the parts of the process, regarding the logistical affairs as well as source separation and collection.

In this case, we found two such successful adaptations: one is the green container design, and the other is the bokashi mix. The green containers were designed by gauging the average amounts of waste generated by households and other places. The container also includes a false bottom to contain leachate and a hermetic lid to prevent odours. This simple but effective design helped GCP to receive the muchneeded public acceptance and improve source separation and collection volumes.

In addition, bokashi used in the containers is also another example for such technology adaptation. EPC conducted a number of trial runs to find the correct combination of bokashi needed. What they use now is the best they found to prevent offensive odours, retain high amounts of leachate, and prevent excess fungi and fruit fly growth (personal communication with Javier Rodríguez, Head of Waste Management of Cajicá's Sanitary Collection Enterprise, May 2018).

\subsection{Putting Nexus Thinking into Practice}

Nexus thinking is a concept that has become popular recently within the environmental resource management circles. It is a way to improve the security of resources by integrating management and governance across sectors and scales, thus reducing trade-offs and building synergies with the overall intention of promoting sustainability (Hoff 2011). Any composting project is a good example to explain the benefits of nexus thinking (Sallwey et al. 2017). When GCP was introduced years ago, Cajicá Municipality may not have considered any aspect of nexus thinking, as the concept itself was in its infancy back then. However, looking back now at how the GCP project had been designed and developed, it is clear that they have employed nexus thinking to address both resources and governance aspects of the project.

From the material resources point of view, cross-sectoral integrated management benefits from synergies. In other words, sustainable management of one resource can also alleviate resource issues in another sector. In this case, the organic waste is a resource that originated from the waste sector, and the compost made from it provides nutrients to the agricultural sector (see Fig. 2.8). The nexus application in 


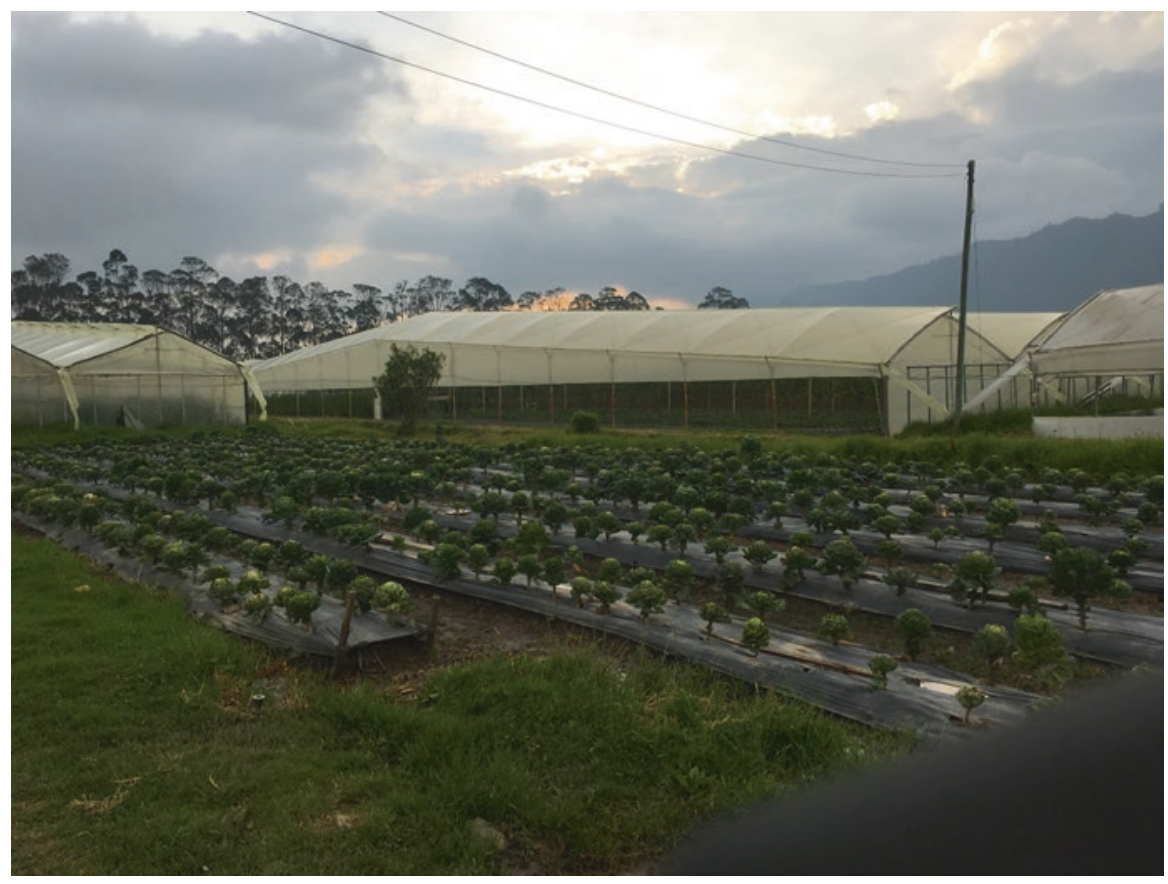

Fig. 2.8 The organic farm located next to IBICOL facility uses compost produced by IBICOL SAS. This is a good example explaining how the agricultural sector benefits from organic waste recycling. (Photo taken by the authors in November 2018 with courtesy of the Facility Manager, Mr. Andrés Botero)

Cajicá also explains the economics of it through cost savings. The municipality is saving money through the reduced amounts of waste that is now going to the landfill. Saving landfill volume is directly visible, but there are other cost savings that might not be easily visible, through transport, oil, drivers, vehicle maintenance, transit tolls, change of tyres, etc. (personal communication with Javier Rodríguez, Head of Waste Management of Cajicá's Sanitary Collection Enterprise, May 2018).

The other aspect of nexus thinking is the policy integration through active stakeholder involvement. As explained in the previous sections, the municipality consulted all other existing policies and involved all stakeholders to come up with the new plan for the GCP development.

\subsection{Concerns}

Built on the experience that spans over a decade, GCP runs smoothly now. Despite all the achievements and strengths of the Cajicá case as described above, there are some important concerns to tackle. In a recent publication, Hettiarachchi et al. (2018a) presented some key limitations and potential issues GCP might face. 
They discussed particularly about the financial wellbeing of the GCP and its high dependency on the municipality. Currently, the organic waste collection system is supported by the municipal government - both financially and politically. As of now the municipality spends about USD 364,000/year to cover the cost of the programme, creating a huge risk in terms of maintaining its stability. This means that any financial issues faced by the municipality can put the programme in jeopardy. Also, this municipal support is subjected to the changes in political will and priorities. The political leadership of the municipality changes every 4 years, resulting in new staff and agenda. Fortunately, mayors in the past 10 years recognised GCP as a priority, but if any new mayor in the future does not see it the same way, he/she can stop the programme or restrict financial assistance. Hettiarachchi et al. (2018a) also suggested the need to introduce a policy instrument where a nominal surcharge is added to their waste collection or utility bill as this works better in the region, to raise money to help the programme achieve financial freedom. Part of the money can be used to reward customers through food vouchers.

Hettiarachchi et al. (2018a) also discussed the rapid population growth in Cajicá and the implications of the resulting increase in waste volume on the GCP. As for the projections made for 2018, the population has increased by $33 \%$ since 2005, and based on Cajicá's household classification statistics (DANE 2014), the middle-class population is growing rapidly. This has resulted in a rapid increase in the waste generation per capita. One person in Cajicá produced $0.58 \mathrm{~kg}$ of waste per day on average in 2009, which has increased to $0.84 \mathrm{~kg}$ by 2014 (Alcaldía Municipal de Cajicá 2015). The rapidly increasing population and waste volume may not allow municipality staff to continue to visit every household door to door to collect organic waste and educate people. The current system already requires a lot of manpower, which will become more challenging to maintain when the municipality must serve a much larger population in the near future. Training citizens to bring their sourceseparated organic waste to centres established by the municipality may relieve the programme from some of the financial obligations (Hettiarachchi et al. 2018a).

The excessive dependency GCP has on external parties is a concern known to EPC (based on personal communication with Cajicá's Sanitary Collection Enterprise, May 2018). They have realised the risk of failure, in the case of composting vendor (IBICOL SAS) failing to do their part in the programme due to reasons such as technical issues, declaring bankruptcy, etc. EPC or the municipality currently do not have a contingency plan for such an event. In the worst-case scenario, the only action they could take is to send the organic waste to a landfill.

\section{Summary and Conclusions}

In this chapter, we presented, reviewed, and critiqued Cajicá's experience in recovery of organic waste to make compost. The key aspects of their success as well as some of the potential concerns were also identified. A summary of our main observations is presented below: 
- Cajicá's Green Containers Program (GCP) was carefully designed with the tools, personnel, and economic resources made available by the municipality. A strong and multidisciplinary planning process was used to achieve the intended goals.

- Coordination between the stakeholders such as the municipality, Sanitary Collection Enterprise (EPC), schools/universities, public institutions, NGOs, waste pickers, and regional environmental authorities was fundamental to collect different viewpoints and advice, which ultimately strengthened the foundation of the project.

- The decision to first run a composting pilot project was commendable. It helped Cajicá to gain some first-hand experience before launching the long-term project.

- Awareness raising in source separation of waste and composting process was conducted using multiple channels. This helped the programme tremendously by educating the public and positively influencing their behaviour towards proper waste management and winning public acceptance. The efforts made to educate the next generation through involving schools and universities is certainly an investment for the future.

- Cajicá's case study also teaches us a lesson about the correct choice of business model. They decided to opt for a network governance model to create a privatepublic partnership (PPP).

- Technology transfer has been a key challenge for waste management projects launched in developing countries. In this context, another lesson we can learn from Cajicá's experience is how well they adapted technology to the local settings.

- Undoubtedly, Cajicá's GCP is a good example to explain the benefits of nexus thinking, where integrated management helps both the waste and agricultural sectors to prosper.

- High dependency of GCP on the municipality for financial support and the dependency on a single external partner for the composting process could be viewed as some concerns that may raise issues in the future.

\section{References}

Adhikari, B. K., Barrington, S., Martínez, J., \& King, S. (2009). Effectiveness of three bulking agents for food waste composting. Waste Management, 29, 197-203.

Alcaldía de Barranquilla. (2015). Plan de Gestión Integral de Residuos Sólidos-PGIRS 2016-2027. Barranquilla, Colombia.

Alcaldía de Bogotá. (2015). Plan de Gestión Integral de Residuos Sólidos -PGIRS 2016-2027. Bogotá, Colombia.

Alcaldía de Medellín. (2015). Plan de Gestión Integral de Residuos Sólidos -PGIRS 2016-2027. Medellin, Colombia.

Alcaldía de Santiago de Cali. (2015). Plan de Gestión Integral de Residuos Sólidos -PGIRS 2016-2027. Santiago de Cali, Colombia.

Alcaldía Municipal de Cajicá. (2015). Actualización del Plan de Gestión Integral de Residuos Sólidos 2016-2027. Cajicá: Municipio de Cajicá.

Alcaldía Municipal de Cajicá. (2018). Municipio de Cajicá. Cajicá, Colombia. www.cajica.gov.co/ informacion-general. Accessed 8 May 2018. 
Banco Mundial. (2015). Estrategia Nacional de Infraestructura - Sector Residuos Sólidos. Bogotá: Consultancy, Departamento Nacional de Planeación.

Colebatch, H. K., \& Larmour, P. (1993). Market, bureaucracy and community: A student's guide to organization. London: Pluto Press. ISBN 0745307620.

Concejo Municipal de Cajicá. (2007). Plan de Desarrollo Municipal 2008-2011. Cajicá: Municipio de Cajicá.

Concejo Municipal de Cajicá. (2011). Plan de Desarrollo Municipal 2012-2015. Cajicá: Municipio de Cajicá.

Concejo Municipal de Cajicá. (2015). Plan de Desarrollo Municipal 2016-2019. Cajicá: Municipio de Cajicá.

DANE. (2005). Boletín Censo general. Bogotá: Departamento Administrativo Nacional de Estadística.

DANE. (2013). Encuesta de Calidad de Vida - Presentación general. Bogotá: Departamento Administrativo Nacional de Estadística.

DANE. (2014). Encuesta Multipropósito - Boletín Técnico. Bogotá: Departamento Administrativo Nacional de Estadística.

DNP. (2016). Nueva Medición de Desempeño Municipal - Resultados. Departamento Nacional de Planeación. colaboracion.dnp.gov.co/CDT/Desarrollo\%20Territorial/MDM/Resultados\%20 Desempe\%C3\%B1o\%20Integral\%202016.xlsx?Web=1. Accessed 17 May 2018.

Ekelund, L., \& Nyström, K. (2007). Composting of municipal waste in South Africa - Sustainability aspects. Uppsala: Uppsala Universitet. ISSN: 1650-8319, UPTEC STS06 012.

Hettiarachchi, H., Meegoda, J. N., \& Ryu, S. (2018a). Organic waste buyback as a viable method to enhance sustainable municipal solid waste management in developing countries. International Journal of Environmental Research and Public Health, 15(11), 2483. https://doi.org/10.3390/ ijerph15112483.

Hettiarachchi, H., Ryu, S., Caucci, S., \& Silva, R. (2018b). Municipal solid waste management in Latin America and the Caribbean: Issues and potential solutions from the governance perspective. Recycling, 3(2), 19. https://doi.org/10.3390/recycling3020019.

Hoff, H. (2011). Understanding the Nexus, background paper for the Bonn 2011 conference. Stockholm: Stockholm Environment Institute.

IBICOL SAS. (2018). https://www.ibicol.com.co/insumos. Accessed 14 May 2018.

Jonas, C., Hesterley, W., \& Borgatti, S. (1997). A general theory of network governance: Exchange conditions and social mechanisms. Academy of Management Review, 22, 914.

Kaza, S., Yao, L., Bhada-Tata, P., \& Van Woerden, F. (2018). What a waste 2.0: A global snapshot of solid waste management to 2050 (Urban Development Series). Washington, DC: World Bank.

Ministry of Housing, Cities and Territories. (2014). Residuos sólidos/metodología PGIRS. Minvivienda. www.minvivienda.gov.co/Residuos\%20Solidos/ Metodolog\%C3\%ADa\%20PGIRS.pdf. Accessed 15 May 2018.

Ministry of Housing, Cities and Territories. (2015). Decree 1077. Diario Oficial de Colombia. Bogotá, Colombia.

Norma Técnica Colombiana. (2004). Productos para la industria agrícola productos orgánicos usados como abonos o fertilizantes y enmiendas de suelo. ICONTEC NTC 5167, 15 de June de 2004, Bogotá, Colombia.

OECD/UN ECLAC. (2014). OECD environmental performance reviews: Colombia 2014. Paris: OECD Environmental Performance Reviews, OECD Publishing. https://doi.org/10.178 7/9789264208292-en.

Ospina, D. (2009). Aprovechamiento Y Valorización De Residuos En Cuatro Municipios De Cundinamarca. Postgraduate Thesis, Bucaramanga: Universidad Industrial de Santander.

Oviedo-Ocaña, E. R., Dominguez, I., Torres-Lozada, P., Marmolejo-Rebellón, L. F., Komilis, D., \& Sanchez, A. (2016). A qualitative model to evaluate biowaste composting management systems using causal diagrams: a case study in Colombia. Journal of Cleaner Production, 133, 201-211.

Pace, S. A., Yazdani, R., Kendall, A., \& Simmons, C. W. (2018). Impact of organic waste composition on life cycle energy production, global warming and water use for treatment by anaerobic digestion followed by composting. Resources, Conservation \& Recycling, 137, 126-135. 
Red de ciudades cómo vamos. (2014). Informe sobre la política pública de inclusión de recicladores de oficio en la cadena de reciclaje: Informe regional. Bogotá: Fundación Avina.

Sallwey, J., Hettiarachchi, H., \& Hülsmann, H. (2017). Challenges and opportunities in municipal solid waste management in Mozambique: A review in the light of Nexus thinking. AIMS Environmental Science - Special Issue: Waste recycling, Reduction and Management, 4, 621-639. https://doi.org/10.3934/environsci.2017.4.621.

Sanitary Collection Enterprise of Cajicá. (2017). Waste management report submitted to the municipal council of Cajicá. Cajicá: Sanitary collection Enterprise.

Superintendence of Public Services. (2017). National report of solid waste final disposal in 2016: National report. Bogotá: Superintendence of Public Services.

Thompson, G., Frances, J., Levacic, R., \& Mitchell, J. (1991). Markets, Hierarchies and Networks. London: Sage.

UN Environment. (2017). Solid approach to waste: How 5 cities are beating pollution. United Nations Environment Program Website. www.unenvironment.org/news-and-stories/story/ solid-approach-waste-how-5-cities-are-beating-pollution. Accessed 8 May 2018.

USEPA. (2016). Inventory of greenhouse gas emissions and sinks: 1990-2014. United States Environmental Protection Agency Website. 15 de April de 2016. 19january2017snapshot. epa.gov/sites/production/files/2016-04/documents/us-ghg-inventory-2016-main-text.pdf. Accessed 26 June 2018.

Wei, Y., Li, J., Shi, D., Liu, G., Zhao, Y., \& Shimaoka, T. (2017). Environmental challenges impeding the composting of biodegradable municipal solid waste: A critical review. Resources, Conservation and Recycling, 122, 51-65.

World Bank. (1994). Governance, the World's Bank experience. World's Bank activities, Washington, DC: World Bank.

The opinions expressed in this chapter are those of the author(s) and do not necessarily reflect the views of the United Nations University Institute for Integrated Management of Material Fluxes and of Resources (UNU-FLORES), its Board of Directors, or the countries they represent.

Open Access This chapter is licensed under the terms of the Creative Commons Attribution 3.0 IGO license (https://creativecommons.org/licenses/by/3.0/igo/), which permits use, sharing, adaptation, distribution and reproduction in any medium or format, as long as you give appropriate credit to the United Nations University Institute for Integrated Management of Material Fluxes and of Resources (UNU-FLORES), provide a link to the Creative Commons license and indicate if changes were made.

Any dispute related to the use of the works of the United Nations University Institute for Integrated Management of Material Fluxes and of Resources (UNU-FLORES) that cannot be settled amicably shall be submitted to arbitration pursuant to the UNCITRAL rules. The use of the United Nations University Institute for Integrated Management of Material Fluxes and of Resources (UNU-FLORES)'s name for any purpose other than for attribution, and the use of the United Nations University Institute for Integrated Management of Material Fluxes and of Resources (UNU-FLORES)'s logo, shall be subject to a separate written license agreement between the United Nations University Institute for Integrated Management of Material Fluxes and of Resources (UNU-FLORES) and the user and is not authorized as part of this CC-IGO license. Note that the link provided above includes additional terms and conditions of the license.

The images or other third party material in this chapter are included in the chapter's Creative Commons license, unless indicated otherwise in a credit line to the material. If material is not included in the chapter's Creative Commons license and your intended use is not permitted by statutory regulation or exceeds the permitted use, you will need to obtain permission directly from the copyright holder.

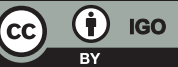

